https://doi.org/10.24101/logos.2021.70

Gauta 20210807

BRIGITA KAIRIENE

Mykolo Romerio universitetas, Lietuva

Mykolas Romeris University, Lithuania

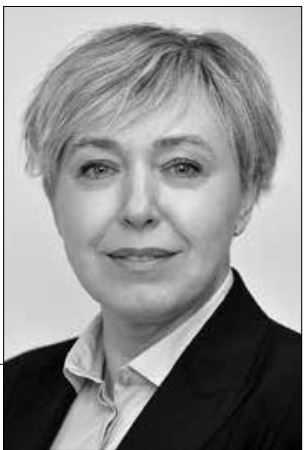

\title{
KŪDIKIŲ KRIKŠTAS GERIAUSIŲ VAIKO INTERESŲ POŽIŪRIU
}

\author{
Infant Baptism in the Best Interests of the Child
}

\section{SUMMARY}

The article deals with infant Baptism from the perspective of the implementation of children's rights. The UN Convention on the Rights of the Child has given children the status of rights holder and active participant, which means that parents' decisions must be in the best interests of the child, which must be determined by giving the child the opportunity to express his or her views on the matter. Most often, infants or young children are baptised who are not yet in a position to express their own opinion, and their baptism is therefore based solely on the will of the parents. This article seeks to answer the question of when a parent's decision to baptize an infant is in the best interests of the child.

\section{SANTRAUKA}

Straipsnyje nagrinëjamas kūdikių Krikštas vaiko teisių igyvendinimo aspektu. JT vaiko teisių konvencija suteikè vaikams teisių turètojo ir aktyvaus dalyvio statusą, o tai reiškia, kad tèvų sprendimai turi atitikti geriausius vaiko interesus, kuriuos nustatant, būtina sudaryti vaikui galimybę išsakyti savo nuomonę nagrinèjamu klausimu. Dažniausiai būna krikštijami kūdikiai arba maži vaikai, kurie dar negali išsakyti savo nuomonès, todèl jų krikštijimas paremtas tik tẻvų valia. Straipsnyje siekiama atsakyti į klausimą, kada tẻvų sprendimas pakrikštyti kūdikị atitinka geriausius jo interesus.

\section{IVADAS}

1989 m. JT vaiko teisių konvenciją [toliau - konvencija] galima laikyti svarbiausiu projektu, dèl kurio i̇vyko per- versmas vaiko teisiu igyvendinimo ir apsaugos srityje keičiant požiūrị i vaiką kaip i lygiaverti šeimos ir visuomenès 
nari pripažistant jo orumą nelygstamą vertę ir ittvirtinant vaiko teisių turètojo statusą. Nors už vaiko teisių igyvendinimą visų pirma atsakingi tèvai, vaiko, kaip savarankiško teisès subjekto, įtraukimas ì su juo susijusių sprendimų prièmimą tapo privalomas.

Viena iš vaiko teisių, dèl savo universalaus taikymo privalomumo tapusi principu, teigia, kad priimant bet koki sprendima, susijusi su vaiku, būtina atsižvelgti i geriausius vaiko interesus. Vaiko interesų turinys konvencijoje nèra apibrèžtas, kadangi interesai yra individualūs, todèl turi būti nustatomi ir igyvendinami kiekvienu atveju konkrečiai. Interesai apima ne tik vaiko gyvenimui ir vystymuisi būtinas sąlygas tam tikru momentu, bet ir jo raidos bei saviraiškos galimybes ateityje. Vaiko interesų nustatymas siejamas su holistiniu požiūriu i vaika, todèl apibūdina ir fizines, ir socialines, ir dvasines, ir dorines augimo ir vystymosi sąlygas. Interesų turinys apima objektyviąsias ir subjektyviąsias prielaidas. Objektyviosios prielaidos sudaro bendruosius vaiko augimui ir raidai būtinus poreikius ir sąlygas - tai sveikata, saugumas, socialinė aplinka, galimybė mokytis, ilsėtis, žaisti, tačiau jų igyvendinimas yra individualizuotas, nes priklauso nuo asmens ypatumų. Subjektyviosios prielaidos leidžia nustatyti kiekvienam asmeniui būdingus, ji dominančius, jam svarbius, reikšmingus dalykus, o jų nustatymas immanomas tik aktyviai dalyvaujant pačiam asmeniui - vaikui. Konvencijoje nėra numatytas amžius, nuo kada vaikas turètų būti išklausytas priimant su juo susijusi sprendimą. Vaiko sąmoningejjimas vyksta pamažu ir individualiai, todèl negalima nubrèžti aiškios amžiaus ribos vaiko nuomonei išsakyti ir / ar laisvai pasirinkti. Tačiau ar priimant sprendimą bus atsižvelgta $i$ vaiko nuomonę, priklauso nuo to, ar vaiko išsakyta nuomonè svarstomu klausimu neprieštarauja jo paties interesams.

Dvasinè raida - vienas vaiko poreikiu, kuriam patenkinti gali būti pasitelkiama religija. Konvencijos 14 straipsnyje numatyta pagarba vaiko teisei i minties, sąžinès ir religijos laisvę, taip pat pagarba tèvų teisei ir pareigai vadovauti vaikui igyvendinant jo teisę taip, kad ji atitiktu besivystančius vaiko gebejimus. Pirmoje straipsnio dalyje pabrěžiama vaiko laisvė apsispręsti dèl religijos, t. y. jo pasirinkimas, ar išpažinti religiją ir jei taip - tai kokią. Tačiau tik pasiekęs dvasinę brandą vaikas gali priimti sąmoningą sprendimą šiuo klausimu, todèl iki tol tèvams, atsakingiems už vaiko teisių igyvendinima, numatyta teisè ir pareiga vadovauti vaikui igyvendinant šią teisę.

Viena iš religijos iprasminimą ir îsitraukimo iz religijos bendruomenę liudijančių apeigų - krikštas. Krikščioniškojo tikèjimo pradžia siejama su Krikštu: „Ir visi, kurie esate pakrikštyti Kristuje, apsivilkote Kristumi“ (Gal 3, 27) - sakoma pakrikštytiesiems. Krikščionis - pakrikštytas ir per Krikštą Kristui priklausantis žmogus, gyvenantis gyvenimą su Dievu. Krikšto sakramento suteikimas nedeterminuotas pagal amžių, tačiau dažniausiai siekiama pakrikštyti kuo mažesnius vaikus, paprastai kūdikius iki vieneriu metų amžiaus. Kūdikių krikštas kilo iš senesnès suaugusiųjų krikšto apeigos dèl didelio kūdikių mirtingumo ir baimès, kad kiekvienam naujagimiui gresia mir- 
tis. Krikštas žadejjo amžiną gyvenimą tiems, kurie galbūt ilgai neišgyvens žemiškojo gyvenimo (Turner 2019). Kadangi kūdikiai dar negali išreikšti savo valios dèl jų krikštijimo, sprendimą priima jų tèvai, kurie turi pareigą vadovautis geriausiais vaiko interesais. Taigi siekiama išsiaiškinti - kokiais atvejais tèvu sprendimas pakrikštyti kūdiki atitinka geriausius jo interesus.

\section{VAIKO TEISĖ | RELIGIJĄ LAISVU PASIRINKIMU}

Atsižvelgiant $i$ tai, kad vaikui augant ir savarankiškejjant jo aktyvumas igyvendinant savo teises turètų didèti, o tèvu mažèti, galima manyti, kad kalbant apie religijos išpažinimą vaikui gimus, tevai natūraliai pažindina vaiką su savo praktikuojama religija (jei tokia yra), o ilgainiui vaikas turètų apsispręsti dèl jos prièmimo arba ne. Be abejonès, vaiko apsisprendimui dèl religijos puoselejjimo esmini vaidmeni turi tèvai ir kiti su religijos praktika susiję asmenys - mokytojai, dvasininkai, religinès bendruomenès nariai ir pan., t. y. autoritetai, kuriu pavyzdžio paveikumas galètų lemti vaiko pasirinkimą.

Skirtingai nuo pirminių ir būtiniausių žmogaus egzistencijai fiziologinių poreikių, kuriuos tėvai privalo tenkinti nuo pat vaiko gimimo, dvasiniai poreikiai atsiranda vèliau ir ju patenkinimo būdas ir priemonès gali būti ìvairūs, nebūtinai religiniai, todèl ju pasirinkimas priklauso pačiam asmeniui ir negali būti kitu parenkami ir primetami. Religija yra privatus reikalas, todèl vaiko teisès ị religiją igyvendinimas neimanomas be vaiko sąmoningumo ir sutikimo. Vaiką galima priversti nueiti į bažnyčią ir atlikti apeigu veiksmus, tačiau negalima priversti tikèti ir išpažinti religijos mokymą. Vaiko teisès į religiją igyvendinimo požiūriu vaikas turètų būti gerbiamas kaip dialo- go partneris, netgi jei jam vis dar reikia mūsų pagalbos ir paramos visais atžvilgiais (Schweitzer 2005). Konvencija, paremta i vaiką orientuota koncepcija, mato vaiką kaip aktyvu santykio dalyvi, galinti pasirinkti dvasiniu poreikiu patenkinimo būdą ar kurti savitą ryši su religija ir nebūtinai toki patí, kaip jo tèvų. Būtina suvokti, kad tyrinejjame žmones, turinčius nuomonę, interesus ir savitą reiškinio interpretacija, o ne idejas ir koncepcijas (Henderick 2008), kurios besąlygiškai turètų būti priimamos. Todèl pirmiausia tèvams būtina surasti pusiausvyrą tarp pagarbos vaiko privačiai sričiai, kuriai ir priklauso religija, ir ju atsakomybès už vaiką.

Daugelis tėvų, būdami tinkamu pavyzdžiu savo vaikams, tėvystę sieja su dideliais lūkesčiais jų atžvilgiu, tikèdamiesi, kad vaikai perims ju gyvenimo būda, tradicijas, papročius, paveldès ju gebejjimus, o tikintys tèvai tikisi, kad ju vaikai pasirinks tą pačią religiją ir tos religijos mokymu iprasmins savo gyvenimą. Tačiau tam tikra religija grindžiamo tikèjimo perdavimas nę̇manomas be priimančiojo - vaiko akceptavimo. Religijos pasirinkimas yra pernelyg asmeniškas, kad galètų būti kažkieno, net ir tẻvų, nulemtas. Vaiko teisès į religiją igyvendinimas įmanomas tik tada, kai vaikas traktuojamas kaip lygiavertis santykio daly- 
vis pripažistant ir gerbiant jo orumą. Todèl religijos pasirinkimas, o ne perèmimas, yra be išimties autonomiškas laisvo apsisprendimo veiksmas, kuris turi būti lydimas brandaus sąmoningumo.

Jauni žmonès savo religinius įsitikinimus laiko savo teise ir atsakomybe, kurią lemia religijos pasirinkimas atskirai nuo jų tèvų religijos (Arnett, Jensen 2002). Vaiko teisè i religiją turi būti suprantama kaip asmeninio poreikio patenkinimas tik jam priimtinu būdu, todèl igyvendinamas tik paties vaiko pasirinkimu, o ne tèvų teisė per vaiko religini švietimą patenkinti savo su religijos praktikavimu susijusius poreikius, ar mokyklos teisè primesti religijos mokymą siekiant igyvendinti švietimo programas, ar religinès bendruomenés teisè $i$ bendruomenės nari, kuriuo jis tampa po krikšto, siekiant auginti bendruomenę.

Religinis ugdymas(-is) apima dvasinę ir religinę dimensijas, kurias per ugdymą realizuoja visu pirma šeima ir bendruomenè. Ugdymas(-is) integruoja ir auklèjima, ir švietimą. Šeima ir religija istoriškai perduodavo vertybes iš kartos i kartą (Bengtson et al. 2013). Dvasinis ugdymasis siejamas su vertybėmis, o ju negalima nei primesti, nei priversti jèga jas interiorizuoti (Aramavičiūtè 2005). Tik suaugusiųjų laikysena, pavyzdys, sukurtas santykis su vaiku turi reikšmę jo vertybinių nuostatų ir atitinkamai - elgesio formavimuisi (Wissink et al. 2014). Vertybių ugdymosi procesui svarbi pateikimo forma - ne reikalaujančia pareigu kalba, bet kreipimusi iz vaiką kaip laisvą ir laisvę suvokiančią asmenybę, kad jis galètų pasirinkti - vertybę priimti arba nepriimti (Kanišauskas 2014).
Taigi vaiko teisè i religiją susijusi su jo teise ị ugdymą(-si), mokymą(-si), švietimą. Tik šiuo atveju iškyla klausimas dèl švietimo turinio privalomumo - kokị ugdymo turini gali vaikas rinktis. Tai priklauso nuo turinio pobūdžio. Viena, ugdymo turinys nulemtas asmens poreikio gyventi visuomenèje tam tikru jos raidos periodu, todel tam tikras turinys yra būtinas. Kas kita - religija, kuri nors ir gali tapti dvasiniu poreikių patenkinimo ir ugdymo(-si) priemone, bet nebūtinai. Konvencijoje apibréžiant vaiko teisę mokytis neminimas dvasingumas ar religija kaip šios teisès igyvendinimo dalis, taigi vaikas neturi teisiniu pretenziju i r religini ugdymą (Schweitzer 2005), o tik prielaida, kuri gali būti arba ne. Žmogus laisvas rinktis gyvenimą be religijos, todèl iškyla vaiko teisès ị religiją be jo sutikimo igyvendinimo klausimas, kuris krikščionių pradedamas Krikštu paprastai dar iki vaiko dvasinio ugdymosi poreikio atsiradimo.

Suaugusiųjų krikštas yra sąmoningas paties krikštijamo laisvo apsisprendimo atsiversti ir priimti tikejjimą kaip Dievo dovaną per Krikštą veiksmas kaip ìvadas i tikejjimą ir krikščioniškajji gyvenimą. Suaugusiojo arba dvasinę brandą pasiekusio vaiko krikštas vyksta paties krikštijamo sutikimu, sąmoningu ir subrandintu veiksmu - troškimu priimti Dievo dovaną ir ketinimu gyventi pagal Evangeliją. Suaugęs krikštijamasis aktyviai dalyvauja krikšto apeigose ir apgalvotai priima sakramentą pasiryžęs savo gyvenimą susieti su Kristumi. Kūdikių krikštijimas vyksta be ju sutikimo ir valios. Tokiu atveju vaikas priima Krikštą dar neprièmęs tikèjimo - Krikšto metu už ji 
tai padaro tėvai. Kūdikiai krikštijami tèvų ar vieno jų sprendimu, nelaukiant, kol jis pats gebės išreikšti savo valia, paremtą aiškiu Krikšto sakramento supratimu.

Krikštas - ne tik apeiga, tai i̇sipareigojimas. Krikštu pradedamas tikejjimas, kuris turi būti ugdomas: „Taigi jūs, Dievo išrinktieji, šventieji ir numylètiniai, apsivilkite nuoširdžiu gailestingumu, gerumu, nuolankumu, romumu ir kantrumu. Būkite vieni kitiems pakantūs ir atleiskite vieni kitiems, jei vienas prieš kitą turite skundą. Kaip Viešpats jums atleido, taip ir jūs atleiskite. Viršum viso šito tebūna meilè, kuri yra tobulumo raištis" (Kol 3, 12-14). Vaiko vardu išreiškę norą būti pakrikštytam tèvai įsipareigoja ji auklèti krikščioniškai. Taigi tik tikëjimas krikšto būtinumu, prasme ir tęstinis įsipareigojimas yra tèvų veikimas vaiko interesais, nes krikšto veiksmu suteikiama katalikiškojo gyvenimo prasmé, vertè ir prielaidos tokiam vaiko gyvenimui atsirasti, kurios ir apibrèžiamos konvencijoje kaip tèvų teisė ir pareiga vadovauti vaikui igyvendinant teisę i religiją. Už krikšto metu gautos malonès puoselejjimą atsakingi ne tik vaiko tèvai, bet ir krikšto tèvai, todèl jie turi būti tikintys ir galintys skatinti, palaikyti, ugdyti krikštijamo tikejjimo išpažinimą.

Vaikui augant, tolesni tèvų veiksmai, susiję su vaiko krikšto tęstinumu per jo religinę praktika, kaip atliepiantys geriausius vaiko interesus, turètu iprasminti vaiko kaip aktyvaus santykio dalyvio vaidmeni ir visavertiškumą priimant sprendimus dèl tikejjimo. Tẻvams būtina siekti pusiausvyros tarp savo religiniu isitikimų ir didejjančio vaiko savarankiškumo bei sąmoningumo suteikiant jam religinę autonomija, gerbiant vaiko pasirinkimą ir religini apsisprendimą sykiu pripažistant jo, kaip žmogaus, unikalumą ir nelygstamą vertingumą. Religinè tapatybė yra ne šeimos palikimo ar tradiciju tęstinumo, o asmeninio pasirinkimo dalykas, kadangi susijęs ne tik su apsisprendimo teise, bet ir asmeniniu isipareigojimu gyventi krikščionišką gyvenimą.

\section{KRIKŠTIJIMO INTENCIJA}

Krikšto reikšmė kyla iš Jėzaus Kristaus mokymo, kuris Nikodemui aiškino: „,jei kas neatgims iš aukštybès, negalès regèti Dievo karalystès. <...> kas negims iš vandens ir Dvasios, neįeis i Dievo karalystę" (Jn 3, 3) ir nurodè vadovautis Jėzaus Didžiuoju pavedimu: „Tad eikite, ir padarykite mano mokiniais visų tautų žmones krikštydami juos vardan Tèvo ir Sūnaus, ir Šventosios Dvasios" (Mt 28, 19). Tèvų santykis su religija determinuotas rūpesčio dèl vaiko dabarties ir ateities. Dabartis iprasmina poreiki apsaugoti vaiką ir suteikti jam viska, kas yra geriausio, pradžioje iš kūdikio pozicijų sukuriant pasyvų santyki su Dievu ir tikintis, kad ateityje vaikas priims tèvų puoselejamą religiją ir sukurs aktyvų santyki su Dievu.

Krikšto asmeninis tikslas - gauti malonių. „Šventasis Krikštas yra viso krikščioniškojo gyvenimo pamatas, prieangis i gyvenimą Dvasioje (vitae spiritualis ianua), vartai į kitus sakramentus. Krikštu mes esame išlaisvinami iš nuodèmès ir atgimstame kaip Dievo vaikai; tapę 
Kristaus nariais, įsijungiame i Bažnyčią kaip jos pasiuntinybès dalyviai" (Kataliku Bažnyčios katekizmas, 1213). Krikštas laikomas durimis į išganymą. Sprendimas pakrikštyti vaiką kyla iš tévų tikejjimo, kuriame Krikštas yra krikščioniškojo gyvenimo pamatas. Poreikis krikštyti vaiką kyla iš tėvų tikëjimo krikšto apeigu svarba ir prasme, kad Krikštu atleidžiamos visos nuodemès - ir gimtoji, ir visos asmeninès, taip pat bausmès už nuodèmes (pgl. DS 1316). Šv. Petras skelbè: „Atsiverskite, ir kiekvienas tepasikrikštija vardan Jėzaus Kristaus, kad būtų atleistos jums nuodèmès, tada gausite Šventosios Dvasios dovaną" (Apd 2, 38). Nebelieka nieko, kas atgimdytiesiems sutrukdytų ieiti i Dievo karalystę, - nei Adomo nuodėmè, nei asmeninè nuodèmè, nei nuodèmès pasekmès, kurių skaudžiausia yra atskyrimas nuo Dievo (plg. Kataliku Bažnyčios Katekizmas, 1263). Krikščionys tèvai Krikštą supranta kaip būtinybę ir savo pareigą vaikui, nes tik per Krikštą vaikas gauna malonę tapti Dievo vaiku: „Leiskite mažutèliams ateiti pas mane ir netrukdykite“ (Mk 10, 14), per Krikštą vaikas gauna Šventosios Dvasios dovaną (Apd 2, 38), galimybę pasiekti išganymą (plg. Jn 3, 5).

Krikšto socialinė paskirtis - tapti religinès bendruomenès nariu. Krikščionybė yra socialinè religija (Wesley 2010), nes tai naujas bendruomeninis gyvenimo būdas ir negali būti teisingo santykio su Dievu, jei mes nesame teisingame santykyje ir vieni su kitais, tiek su savo artimaisiais, tiek su priešais (Long 2018). Kaip teigia Long, teisingu santykiu tikslas - prisidèti prie misijos, kelionès i Naujajji miesta, o tai reiškia pereiti nuo pradinio perëjimo per Krikšto vandenis prie nuolatinès atgailos praktikos. Toks judejimas skirtas sutaikinimui igyvendinti, kurio tikimès bendraudami su Dievu ir kitais. Per Krikštą mes dalijamès Trejybės meile gyvenime, todèl mūsų krikščioniškasis gyvenimas yra ne privatus reikalas, mes de facto esame bendrystejje ne tik su Dievu, bet ir su visais kitais tikinčiaisiais (Burns 2018).

Krikštas yra ne tik bažnyčios sakramentas, bet ir socialinis veiksmas, žymintis asmens perëjimą iš pasauliečio i visateisį tikèjimo bendruomenès narị. $\breve{S} i$ ceremonija konstruoja kaimynystès, bendruomenès ir giminystès ryšius, kartu turi religinę reikšmę vaikui, šeimai ir parapijai (Cressy 1999). Vaikas Krikštu igyja naują socialini statusą, rodanti jo religini tapatumą ir priklausymą religinei bendruomenei. Krikštu bendruomené ipareigojama ivesdinti naują nari i dvasini kelią, kuris neapsiriboja tik savo santykio su Dievu kūrimu, santykio su kitais kūrimu ir puoselëjimu krikščioniu bendruomeneje, bet įsipareigojimu ir savo žodžiais bei veiksmais liudyti Dievo galybę savo gyvenime.

Pats Krikšto aktas turi būti prasmingas turint tikslą pakeisti asmens gyvenimą. Krikštas turi reikšmę tik tada, kai puoselëjamas ir ugdomas, priešingu atveju tai yra tik ritualinès išraiškos poreikio patenkinimas, apeiga, sutelkta tik $\mathfrak{i}$ jos atlikimo forma, bet ne i turini ir tikslą tikejjimo pradžia, kuriam reikia tolesnio nuolatinio dvasinio tobulëjimo iprasminant krikščionišką tikejjimą ir gyvenimą.

Siekiant nustatyti, ar Krikštas atitinka geriausius vaiko interesus, kai vaikas dar negali išreikšti savo valios, pakanka tèvų 
paklausti: kokiais ketinimais vadovaudamiesi krikštija vaiką? Atsakymas parodytu, koks Krikšto intencijos turinys, kokią prasmę tėvams suteikia vaiko Krikštas. Tikinčiu tèvų siekis pakrikštyti vaiką gali turèti įvairias prasmes. Visu pirma prigimtini poreikị saugoti ir globoti vaiką ir suteikti jam svarbiausius ir būtiniausius dalykus. Bažnytinè katechezė akcentuoja krikšto būtinuma, nes Krikštas yra viso krikščioniškojo gyvenimo pamatas (Kataliku Bažnyčios katekizmas, 1213) ir būtina sąlyga amžinajam išganymui: „Kas negims iš vandens ir Dvasios, neįeis į Dievo Karalystę. Kas gimè iš kūno, yra kūnas, o kas gimè iš Dvasios, yra dvasia“" (Jn 3, 5-6). Taigi Krikšto pakanka, kad vaikas būtų išgelbètas. Suprasdami sakramentinę Krikšto apeigu prasmę kaip išganymo proceso vyksmą ir amžinojo gyvenimo dovana, tèvai vykdo ir tèviška, ir krikščionišką pareigą. Antra, tikintys tèvai savo kūdikius krikštija šitaip liudydami savo tikejjimą: „Leisk Krikšto malonei šventumo kelyje duoti vaisių. Viską atverk Dievui ir vis iš naujo rinkis Dievą. Neprarask drąsos, nes turi Šventosios Dvasios jègos, kad tai būtų įmanoma. Juk šventumas tavo gyvenime iš esmès yra Šventosios Dvasios vaisius" (plg. Gal 5, 22-23). Trečia, tèvai trokšta dalytis gyvenimu su savo vaiku ne tik šiame gyvenime, bet ir kitame pasaulyje. Kaip sako šv. Paulius Laiške romiečiams: „Argi nežinote, jog mes visi, pakrikštytieji Kristuje Jėzuje, esame pakrikštyti jo mirtyje? Taigi krikštu mes esame kartu su juo palaidoti mirtyje, kad kaip Jėzus buvo prikeltas iš numirusių Tẻvo šlovinga galia, taip ir mes pradetume gyventi atnaujin- tą gyvenimą" (Rom 6, 3-4). Ketvirta, tikintys tèvai trokšta, kad ju vaikai rastu prasmę ir tikslą tose pačiose religinèse dogmose, kurias jie išpažista. Tikėdami, kad vaikas, Krikštu iqvesdinamas ị religiją bus linkęs išsaugoti tèvų inicijuotą religinę tapatybę ir tęsti tẻvų veiksmais pradètą savo religini ippareigojimą ir įsipareigoti tęsti tèvų religiją. Kol vaikas mažas, artimieji yra vieninteliai religiniu tradiciju ir įsitikinimu skleidejjai ir perteikejjai. Kokia bus vaiko religinè patirtis - ar paaugęs vaikas galès laisvai rinktis savo tikèjima, ar ji keisti, priklausys nuo tèvų ir vaiku santykio - ar jis bus lygiavertis, orientuotas ị vaika, grindžiamas pagarba vaiko žmogiškam orumui. Taigi vaiko krikštijimas atitinka geriausius jo interesus, jei Krikštas turi religinę reikšmę, iprasminančią tèvų tikẻjimą ir sieki Krikšto sakramentu apsaugoti vaiką ir perduoti ji Dievo malonei prisiimant issipareigojimą ivesdinti ji i i religijos išpažinimą.

Tačiau tèvai gali turèti daugiau simbolinį nei sakramentinį Krikšto supratima, siekia tik išlaikyti šeimos tradicijas. Šiuo atveju, kai vaikas krikštijamas dèl šventinio ritualo tradicijos, apeigu, nes taip iprasta, taip tèvai ir proteviai darè, ar dar blogiau - dèl patiriamo artimujju spaudimo, nes taip reikia, Krikštas tampa tik veiksmu seka, ịvilkta ị šventės formatą. Atliekant Krikšto apeigas, susidaro sakralumo ispūdis, tačiau jei jo reikšme netikima, siekis neiprasmintas turiniu, Krikštas būna atskirtas nuo tikejjimo matmens neturint intencijos ji plètoti, apeiga konvertuojama iz tuščią simboli ir tampa tik pramoginiu papročiu. Jei Krikšto tikslas yra šventė, o šven- 
timas sutelktas ị rituală kad būtu galima paminèti vieną iš gyvenimo ivykių ir formaliai pažymèti atliktą veiksmą, tai toks Krikštas atitinka tèvu, galbūt artimuju, bet ne vaiko interesus. Tokiu atveju tenka pripažinti, kad Krikšto ritualas, būdamas formalus, netenka savo prasmès, nes tèvu pasirinkimas kyla iš pasaulietinių tèvų paskatų neturint sakramento intencijos ir igauna tik ritualini pavidalą pasaulietiniam žmogui išlaikant apeigu tradiciją.

\section{IŠVADOS}

Vaikas yra tèvų globos ir rūpesčio dèl jo dabarties ir ateities atspindys, todèl tèvų veiksmai turètų atitikti geriausius vaiko interesus. Ar vaiko krikštijimas tokius atitinka, priklauso nuo tèvu intencijos. Jei tèvų intencija kyla iš ju pačiu tikejjimo, iprasminto Krikšto sakramento turiniu ir siekiu per Krikštą

\section{Literatūra}

Aramavičiūtè Vanda. 2005. Auklèjimas ir dvasiné asmenybès branda. Vilnius: Gimtasis žodis.

Arnett Jeffrey Jensen, Jensen Lene Arnett. 2002. A congregation of one: Individualized religious beliefs among emerging adults. Journal of Adolescent Research 17: 451-467.

Bengtson Vern L., Putney Norella M., Harris Susan. 2013. Families and faith: How religion is passed down across generations. New York, NY: Oxford University Press.

Burns Dorothy. 2018. The Six Tasks of Catechesis. Fully Alive: 10-12.

Cressy David. 1999. Birth, Marriage, And Death: Ritual, Religion, and the Life-Cycle in Tudor and Stuart England. Oxford: Oxford University Press.

Hendrick Harry. 2008. The Child as a Social Actor in Historical Sources: Problems of Identification and Interpretation, James A., Christensen P. (eds.), Research with Children: Perspectives and Practices: 40-65. New York: Routledge.

Kanišauskas Saulius. 2014. Aksiologijos juadas. Vilnius: Mykolo Romerio universitetas. vaiką apsaugoti ir perduoti Dievo malonei sykiu prisiimant įsipareigojimą ivesdinti ji i religijos išpažinima, vaiko krikštijimas atitinka geriausius jo interesus. Krikštui suteikiant tik apeigos prasmę, atsietai nuo tikejjimo dimensijos, jis virsta pramoga, kurioje nèra vaiko interesų.

Kataliku Bažnyčios katekizmas. 2015. Vilnius: Katalikų pasaulio leidiniai.

Long D. Stephen. 2018. Being Good Pharisees: The Joy of Inauthentic Community. Christian Higher Education 17(5): 290-295.

Schweitzer Friedrich. 2005. Children's right to religion and spirituality: legal, educational and practical perspectives. British Journal of Religious Education 27 (2): 103-113.

Šventasis raštas. 1990-1992. Vilnius: Vaga.

Turner Paul. 2019. Considering the Baptism of Edgardo Mortara in the Context of Catholic Teachings and Rituals Then and Now. Studies in Christian-Jewish Relations 14(1): 1-9.

Wesley John. 2010. The sermon on the mount. Plainfield, NJ: Bridge-Logos Publishers.

Wissink Inge B., Deković Maja., Stams Geert-Jan, Asscher Jessica J., Rutten Esther, Zijlstra Bonne H. 2014. Moral Orientation and Relationships in School and Adolescent Pro- and Antisocial Behaviors: A Multilevel Study. Journal Of School Nursing 30(3): 216-225. 